\section{Fluctuations in C-reactive protein in a hepatoblastoma patient with thrombocytosis}

\author{
Yuya Sato, ${ }^{1}$ Ayaka Kokubu, ${ }^{1}$ \\ Keitaro Fukushima, ${ }^{1}$ Mayuko Okuya, ${ }^{1}$ \\ Susumu Hagisawa, ${ }^{1}$ \\ Hidemitsu Kurosawa, ${ }^{1}$ Kenichi Sugita, ${ }^{1}$ \\ Osamu Arisaka, ${ }^{1}$ Kentaro Okamoto, ${ }^{2}$ \\ Takashi Tsuchioka ${ }^{2}$
}

'Department of Pediatrics; ${ }^{2}$ Department of Pediatric Surgery, Dokkyo Medical

University, Japan

\begin{abstract}
We observed the changes in serum levels of interleukin 6 (IL-6) and C-reactive protein (CRP) in a patient with hepatoblastoma exhibiting thrombocytosis. The concomitant changes of IL-6 and CRP concentrations after the initiation of chemotherapy, in the absence of infection, suggested that the IL-6, which is synthesized in hepatoblastoma cells and induces thrombocytosis, also stimulated CRP production in the present case. IL-6 is thought to play an important role in thrombocytosis in hepatoblastoma.
\end{abstract}

\section{Introduction}

Hepatoblastoma is a commonly in the same phrase primary liver tumor of childhood, and marked thrombocytosis is commonly observed in hepatoblastoma patients. ${ }^{1-4}$ Interleukin 6 (IL-6), which stimulates inflammatory thrombocytosis via thrombopoietin, is also elevated in hepatoblastoma patients with thrombocytosis., ${ }^{2,7}$ In this study, we examined a fivemonth-old girl with hepatoblastoma who also had thrombocytosis. We observed increases in her C-reactive protein (CRP) and IL-6, in the absence of infection, after chemotherapy. Therefore, we inferred that IL-6 induces both thrombocytosis and elevated CRP in hepatoblastoma patients.

\section{Case Report}

A five-month-old girl was admitted to our hospital with abdominal distention. A physical examination revealed a solid mass $(10 \times 12$ $\mathrm{cm}^{2}$ ) in her right upper abdominal quadrant. Her white blood cell (WBC) and platelet counts were $15.6 \times 10^{9} / \mathrm{L}$ and $94.8 \times 10^{9} / \mathrm{L}$, respectively. Her serum liver enzymes were minimally ele- vated and her CRP was $2.24 \mathrm{mg} / \mathrm{dL}$ (normal range: $0-0.3 \mathrm{mg} / \mathrm{dL}$ ). Her $\alpha$-fetoprotein was markedly elevated at $4.0 \times 10^{6} \mathrm{ng} / \mathrm{mL}$ (normal range in five-month-old infants: $8-800 \mathrm{ng} / \mathrm{mL}$ ). A pathology examination through hepatoblastoma of combined fetal and embryonal types. Computed tomography (CT) and magnetic resonance imaging (MRI) revealed that a solid mass had developed in the right lobe of the liver. From these radiological examinations, her stage was diagnosed as PRETEXT III. Chemotherapy was administered according to the Japanese Study Group for Pediatric Liver Tumor Protocol 2 (JPLT-2) with the CITA regimen: cisplatin $\left(80 \mathrm{mg} / \mathrm{m}^{2}\right)$ on day 1 and tetrahydropyranil-adriamycin $\left(30 \mathrm{mg} / \mathrm{m}^{2}\right)$ on day 2. However, the calculated dose was reduced by $70 \%$ based on her age (less than one year old) at first diagnosis, according to the JPLT-2 protocol. Her general condition was good, but her CRP increased from 2.4 to 11.2 $\mathrm{mg} / \mathrm{dL}$ on day 7 after chemotherapy (Table 1). Her WBC count and procalcitonin, which are known to be sensitive markers of bacterial infection, were not elevated. Although no bacteria were detected in her blood, urine, or throat cultures, iv antibiotics for seven days. Her CRP levels were not influenced by the administration of antibiotics. The patient's CRP dropped to $2.4 \mathrm{mg} / \mathrm{dL}$ after four weeks without antibiotics (Table 1). A 50\%-reduced CITA regimen was then administered again, based on the JPLT-2 protocol for six-month-old patients, and we monitored her CRP and IL-6 levels. Her CRP was $2.4 \mathrm{mg} / \mathrm{dL}$ and IL-6 was $17.1 \mathrm{pg} / \mathrm{mL}$ (normal range: 1.0-4.0 pg/mL) before chemotherapy, and both increased to $7.9 \mathrm{mg} / \mathrm{dL}$ and $103.0 \mathrm{pg} / \mathrm{mL}$, respectively, seven days after chemotherapy. CRP (1.1 mg/dL) and IL-6 $(11.2 \mathrm{pg} / \mathrm{mL})$ were restored after 28 days, without injected antibiotics (Table 1). After the complete surgery of hepatoblastoma, CITA was repeated 6 times, IL- 6 was decreased to1.6 $\mathrm{pg} / \mathrm{mL}$ and both of CRP and platelet counts was kept in normal range.

\section{Discussion}

Thrombocytosis was previously recognized as a common complication in hepatoblastoma patients. ${ }^{1-4}$ Elevated serum IL-6 in hepatoblastoma patients with thrombocytosis was previously reported., ${ }^{2,-7}$ Therefore, IL-6, which is synthesized in hepatoblastoma cells6, stimu-

Table 1. C-reactive protein and Interleukin-6 concentrations in a hepatoblastoma patient during chemotherapy.

\begin{tabular}{lcccccc} 
& Pre-treatment & Week 1 & Week 4 & Week 5 & Week 9 & Post-treatment \\
\hline CRP (mg/dL) & 2.4 & 11.2 & 2.4 & 7.9 & 1.1 & 0.2 \\
IL-6 (pg/mL) & NA & NA & 17.1 & 103.0 & 11.2 & 1.6 \\
\hline
\end{tabular}

Correspondence: Yuya Sato, 880 Kita-Kobayashi, Mibu, Shimotsuga, Tochigi 321-0207, Japan. Tel. +81.282.86.1111 - Fax: +81.282.86.2947. E-mail: syuya@dokkyomed.ac.jp

Key words: hepatoblastoma, thrombocytosis, C-reactive protein, interleukin-6.

Received for publication: 27 May 2011. Accepted for publication: 22 July 2011.

This work is licensed under a Creative Commons Attribution NonCommercial 3.0 License (CC BYNC 3.0).

(C) Copyright Y. Sato et al., 2011

Licensee PAGEPress, Italy

Clinics and Practice 2011; 1:e56

doi:10.4081/cp.2011.e56

lates thrombocytosis via thrombopoietin. ${ }^{3,8}$

IL-6 also regulates the production of CRP at the transcriptional level in hepatocytes. ${ }^{9,10}$ Fluctuations in CRP were observed in our patient and a low-grade elevation of CRP (less than $2.0 \mathrm{mg} / \mathrm{dL}$ ) continued between her chemotherapy sessions. About one week after chemotherapy, her CRP had increased from the primary level to $10.5 \mathrm{mg} / \mathrm{dL}$, with no symptoms of infection. The patient's level of procalcitonin, a marker of infection, and WBC count were within normal ranges. All bacterial cultures were also negative. The elevation of IL-6 followed the same ascending course with CRP concentration. This phenomenon indicates that IL- 6 triggered the production of CRP in hepatocytes, similar to the production of thrombopoietin. The serum concentration of IL-6, which is released from damaged hepatoblastoma cells after chemotherapy, increased and up-regulated the expression of CRP. Serum IL-6, CRP and platelet count were normalized after JPLT-2 protocol was performed completely. We consider that the fluctuations in CRP without infection are high suggestive for hepatoblastoma. It is important to determine whether antibiotics are necessary in hepatoblastoma patients after chemotherapy. We believe that the changes in IL- 6 levels paralleled the elevation of CRP in the serum of our hepatoblastoma patient. We conclude that IL-6 production was induced in the hepatoblastoma cells, as a result of the destruction of these cells during chemotherapy, the serum IL-6 concentration increased, causing an increase in serum CRP and thrombocytosis. 


\section{Conclusions}

We reported the changes in serum levels of interleukin 6 (IL-6) and C-reactive protein (CRP) in a patient with hepatoblastoma exhibiting thrombocytosis. The elevation of IL6 paralleled the increase in the serum CRP concentration.

\section{References}

1. Hwang SJ, Luo JC, Li CP, et al. Thrombocytosis: a paraneoplastic syndrome in patients with hepatocellular carcinoma.
World J Gastroenterol 2004;10: 2472-7.

2. Komura E, Matsumura T, Kato T, et al. Thrombopoietin in patients with hepatoblastoma. Stem Cells 1998;16:329-33.

3. Komura-Naito E, Matsumura T, Sawada T, et al. Thrombopoietin in patients with hepatoblastoma. Blood 1997;90:2849-50.

4. Yamaguchi H, Ishii E, Hayashida Y, et al. Mechanism of thrombocytosis in hepatoblastoma: a case report. Pediatr Hematol Oncol 1996;13:539-44.

5. Hollen CW, Henthorn J, Koziol JA, Burstein SA. Serum interleukin-6 levels in patients with thrombocytosis. Leuk Lymphoma 1992;8:235-41.

6. von Schweinitz D, Hadam MR, Welte K, et al. Production of interleukin-1 beta and interleukin-6 in hepatoblastoma. Int $\mathbf{J}$ Cancer 1993;53:728-34.

7. von Schweinitz D, Schmidt D, Fuchs J, et al. Extramedullary hematopoiesis and intratumoral production of cytokines in childhood hepatoblastoma. Pediatr Res 1995;38:555-63.

8. Kaser A, Brandacher G, Steurer W, et al. Interleukin-6 stimulates thrombopoiesis through thrombopoietin: role in inflammatory thrombocytosis. Blood 2001;98:2720-5.

9. Black S, Kushner I, Samols D. C-reactive Protein. J Biol Chem 2004;279:48487-90.

10. Volanakis JE. Human C-reactive protein: expression, structure, and function. Mol Immunol 2001;38:189-97. 